\title{
The Development of E-Module to Improve Learning Results Introduction to Accounting I
}

\author{
Togi Martua Damanik ${ }^{1}$, Saidun Hutasuhut ${ }^{2}$, Fitrawaty ${ }^{3}$ \\ ${ }^{1}$ PPs for Economic Education, Universitas Negeri Medan, Indonesia \\ ${ }^{2,3}$ Universitas Negeri Medan, Indonesia \\ togiambarita9@gmail.com
}

\begin{abstract}
To realize the success of improving education, efforts must be made from various sides, namely paying attention to all components that play an important role such as improving the quality of lecturers, curriculum, facilities and infrastructure, management and community participation. E-module with the sigil application really helps students in lectures because the tutorial content facility supports both descriptions in text, images, and videos so that students have an interest, are able to understand and review learning materials properly and motivate them to study independently. The objectives of this study are: 1) to produce problem solving-based e-modules that are suitable for use in learning, 2) to determine the effectiveness of e-modules developed in improving learning outcomes. Introduction to accounting I. This type of development research uses the Borg \& Gahl model with the Dick $n$ Carey development model. The results showed; (1) The instructional media expert test is at very feasible criteria (80.26\%), (2) the learning design expert test is in the appropriate criteria (75\%), (3) the material expert test is at very feasible criteria (92.5\%), (4) small group trials are in very feasible criteria (84.16\%) (5) Limited field trials are in very feasible criteria $(81.79 \%)$. Based on the results of the feasibility assessment of the developed problem solving-based $e$ module with the percentage of the average score of the overall variable score of $82.74 \%$, it is included in the "very feasible" category, meaning that the developed e-module is proven to be feasible for use.
\end{abstract}

Keywords

e-module; learning

outcomes; introduction to accounting 1

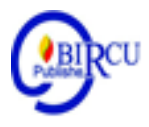

\section{Introduction}

Advances in Information Technology have been widely used in supporting learning activities. One of them is the use of e-modules as a supplement or as a complement for learning activities online. The rapid development of electronic device technology has been able to accelerate the use of electronic devices in learning as part of the development of information technology. In line with these technological developments, the use of information technology as part of the learning media is believed to be able to affect the achievement of students' competencies in following the learning process.

The use of e-modules, apart from reasons of relatively cheaper cost when compared to print technology, is also for other, more fundamental reasons, namely human resource development in the field of Information Technology (IT). If the e-module can be developed and used as a student learning facility in schools, there will be a significant added value, not only to the improvement of the quality of the learning processes and products in the field of study, but also to increase the competence of students in IT. 
One of the things that can be applied to overcome the problems that exist in delivering the introductory accounting material $\mathrm{I}$ is to compile appropriate teaching materials and adjust to the right learning methods in the learning process by paying attention to existing competencies. For this reason, the improvement of the learning process in the classroom can be emphasized on aspects of learning activities. This aspect is directly related to the responsibility of the teaching faculty in fostering students to be more motivated to learn. Learning will be interesting if there is integration between the choice of strategy or learning method with teaching materials that are in accordance with the material presented. Learning strategies must be packaged in such a way that the teaching materials presented are able to overcome problems that occur in the surrounding environment. Learning material is often abstract or outside the experience of students in their lives so that the subject matter will be difficult for students to teach and understand. Abstract subject matter can be visualized using electronic modules

Based on this, the development of e-modules is one of the appropriate media to support learning introductory accounting I because of the need for a guide that makes it easier for students to learn the material. As teaching material in the form of media using electronic devices designed for students to study both independently and online. Modules are also called media for independent study because they include instructions for independent study.

\section{Review of Literatures}

\subsection{The Nature of Learning Introduction to Accounting}

In life, every time there is a learning process, whether intentional or not, whether humans realize it or not. The learning process occurs because there is an interaction between a person and their environment. Therefore, the learning process can occur anywhere. "Learning is a natural process that leads to changes in what we know, we can do and how to behave" Gagne \& Wagner (2005: 1). Learning is a natural process that not only causes changes in the level of knowledge but also in attitudes and behavior.

In general, learning is defined as individual changes that occur through experience, and not because of the growth or development of the body or the characteristics of a person from birth (Trianto 2014: 16). Learning takes place in a complex social environment and should not be limited at the individual level, instead it is necessary to think of learning as a social activity that involves people, the things they use, the words they speak, the cultural context they face, and the actions they take. they take.

Learning is an important activity for every individual. In daily activities humans must not be separated from learning activities, both doing activities individually and in groups. According to Slamento (2010: 2), learning is an effort made by a person to obtain a whole new behavior change, as his own experience in interaction with his environment. Agree with Skinner (2013: 28) argues that learning can be understood, explained and predicted as a whole through observed events, namely the behavior of students and their antecedents and consequences on their environment. Antecedents refer to cues that occur in the environment which indicate conformity with the behavior being carried out.

Dimyati and Mudjiono (2006: 17) argue that learning is a complex thing. The complexity of learning can be seen from two subjects, namely learners and teachers. From the learner's side, learning can be experienced as a process. Learners experience a mental process in dealing with learning materials. From the teacher's point of view, the learning process appears as learning behavior about something. 
Therefore, in the learning process it is seen as a learning behavior about something. Learning is also a complex internal process in which the whole mental process involves the cognitive, affective and psychomotor domains. Furthermore, from the teaching point of view, the learning process can be observed indirectly. In the learning process, the teacher is no longer an information center (teacher centered), but as a learning manager who is always ready to guide and assist students in learning (Utomo, 2020).

\subsection{E-Module}

E-Module is a module / teaching material that uses electronic media in the form of computers, laptops and smartphones in delivering material to be taught to students in class. Several electronic devices that can be combined to build an electronic module are: 1) Microsoft Office Power Point, 2) Microsoft Office Word, 3) Software (applications) and the Web.

According to Mahayuki (2013: 266), e-module is a module that is combined with Information and Communication Technology (ICT), has an interactive nature, is easy to use, can display audiovisuals to make it easier to understand the material, and is equipped with formative tests or quizzes that allow immediate automatic feedback. One learning strategy that is considered adaptive to the development of ICT and can increase students' interest and learning independence is a blended learning strategy (Resien, 2020). Agree with Sadiman (2011: 47) who states that the use of computers, smartphones as learning media not only follows the times in terms of technological advances but also to achieve learning objectives, where the design is adjusted to educational concepts.

Based on the above opinion, it can be concluded that e module is a teaching material combined with Information and Communication Technology (ICT), has an interactive nature, is easy to use, can display audiovisuals to make it easier to understand the material, and is equipped with formative tests or quizzes.

\subsection{Sigill Software}

Sigilis an application (software) editor for Epub which is open source. Epub (electronic publication) is a digital format which is a standard form format introduced by IDPF (International Digital Publishing Forum) in 2011. Epub, a replacement application for Open e-Book that functions as an electronic book format and can be accessed from files of type html, xhtml, xml, css files that are made into a single file with the extension Epub. The advantage of the Epub format is that there are various features that can be used to modify the appearance of eBooks on Epub. Such as the availability of commands that are used to insert video and audio files other than text and images, thereby enhancing the appearance of the book. In addition, Epub is also friendly and supports many devices, such as Android smartphones (using Ideal Reader, FBReader0,

The features contained in sigil include: (1) Epub 2 with support specifications, (2) Multiple views: book, code and preview, (3) Editing WYSIWYG in book view, (4) List of Generator contents with title support mutli-level, (5) Metadata Editor with full support for all metadata entries, (6) Spell checking by default and user dictionaries, (7) Full reuler expression (PCRE) support for searching and replacing, (8) EPUB import support and HTML files, images, and style sheets, (9) integrated API for external HTML and graphics editors, (10) Flight Crew EPUB integration for EPUB compliance validators.

The advantages of the Sigil application are; (1) Freeware digital book maker application with the most complete features of other digital book makers today (2) Exploratory material coverage, which encourages students to seek as much information as possible from various sources (3) Innovative, which raises new things in the approach to 
presenting a concept (4) The E-Module as a learning medium is equipped with video tutorials as suggestions to clarify understanding of the material being reviewed, exercises / tests / evaluations that are interactive and can provide immediate feedback (5) Emodule is equipped with navigation that makes it easy for readers to navigate the module content precisely

While the weaknesses of this software are (1) The existence of video is still in MP4 format, (2) Layout cannot be made multipage (only single page). The e-module developed using the sigil application makes e-module an innovative, easy-to-use teaching medium, has complete material content with training and evaluation video tutorials so that the information received by students is clear and interesting and can stimulate students to deepen their knowledge and make learning not boring.

\section{Research Methods}

This research was conducted at the Faculty of Economics, University of HKBP Nommensen Medan, having its address at Jl. Sutomo No. 4A Medan, North Sumatra. The population in this study were students of the Faculty of Economics at the University of HKBP Nommensen Medan as many as 6 classes, namely class AA1 to class AA6. Samples were part of the number and characteristics possessed by the population, and the samples in this study were AA4 and AA 5 classes. The sampling used was simple random sampling technique

This development research was carried out based on the Borg \& Gahll research and development model which aims to produce educational products through stages.

Due to time and cost limitations, in this case the researcher only carried out steps 1 to 9 . Revise the product after the trial until the product is ready to be validated, then testing the effectiveness of the product developed is done with a quasi-experimental (Quasi Experiment), namely by only comparing the differences in the final test scores learned using problem solving-based e-modules with the final test being taught without using problem solving-based e-modules.

The e-module treatment stage in this study divided the research group into two groups, namely the experimental group (learning using problem solving-based e-modules) and the control group (using conventional modules). The treatment stages are stated in table 1 below:

Table 1. Research Design

\begin{tabular}{|c|c|c|c|}
\hline CLASS & Pretest & Treatment & Posttest \\
\hline E & O1 & X1 & O 2 \\
\hline K & O3 & X2 & O4 \\
\hline
\end{tabular}

(Adapted from Sugiyono, 2013: 116)

Data analysis in this study used quantitative descriptive analysis. All data collected were analyzed using descriptive statistical techniques which are quantitatively separated according to categories to sharpen the judgment in drawing conclusions. Qualitative data in the form of statements that are very feasible, feasible, quite feasible, not feasible to be converted into a quantitative scale with a value scale of 1 to 4 . The results are averaged and used to assess product quality. The eligibility criteria obtained were converted into a value using a Likert scale which was analyzed descriptively by the percentage using the formula:

$$
\mathrm{X}=\frac{\text { Observation Value }}{\text { Expected Value }} \times 100
$$


So that the percentage of eligibility can be explained as follows:

- $0 \%<$ Eligibility $\leq 25 \%$ is not feasible

- $25 \%<$ eligibility $\leq 50 \%$ less feasible

- $50 \%<$ eligibility $\leq 75 \%$ feasible

- $75 \%<$ eligibility $\leq 100 \%$ very feasible

The range of scores from the product eligibility criteria (Arikunto, 2012: 54) is described in the following table:

Table 2. Eligibility Criteria for E-module

\begin{tabular}{|l|l|l|}
\hline No. & Score Range $($ value $)$ & Category \\
\hline 1 & $\mathrm{Mi}+1,5 \mathrm{Sbi}<\mathrm{XI} \leq \mathrm{Mi}+3 \mathrm{Sbi}$ & Very Worth it \\
\hline 2 & $\mathrm{Mi}<\mathrm{XI} \leq \mathrm{Mi}+1,5 \mathrm{Sbi}$ & Well worth it \\
\hline 3 & $\mathrm{Mi}-1,5 \mathrm{Sbi}<\mathrm{XI} \leq \mathrm{Mi}$ & Decent enough \\
\hline 4 & $\mathrm{Mi}-3 \mathrm{Sbi}<\mathrm{XI} \leq \mathrm{Mi}-1,5 \mathrm{Sbi}$ & Less \\
\hline
\end{tabular}

(Arikunto, 2012: 54)

Data analysis in experimental research in this study using quantitative analysis techniques. Before testing the hypothesis, first the requirements test is conducted, namely the normality test and the homogeneity test. The normality test is carried out to determine whether the score of the variable under study comes from a normally distributed population. The normality test was carried out using the Kosmonov-Smirnov normality test. Data obtained from pre-test and post-test data from the experimental group and the control group on the basis of decision making, namely: If the Significance Value (sig)> 0.05 , then the data is normally distributed, if the Significance Value (sig) $<0.05$, then the data are not normally distributed. The homogeneity test was carried out to see whether the data obtained in this study were homogeneous.

To see whether there is a significant difference between learning outcomes and the use of e-module products and without products, a hypothesis test is carried out using the $t$ test by using the formula:

$t=\frac{z_{1}-z_{z}}{s \sqrt{\frac{1}{n_{1}}+\frac{1}{n_{2}}}}$ (Sudjana, 2009)

Where $\mathrm{S}$ is the root of the combined variance calculated by the formula

$S^{2}=\frac{\left(n_{1}-1\right) S_{1}^{2}+\left(n_{2}-1\right) S_{1}^{2}}{n_{1}+n_{2}-2}$

In this study, the differences in treatment were analyzed by using different tests $\mathrm{T}$ test (Independent Samples Test) to analyze the effect of e-module media in improving learning outcomes. The data tested is data on learning outcomes (post-test) the experimental class and the control class.

The criteria for making testing decisions can be seen from the significant level p (Sig (2-tailed)) at $\square 0.05$ as follows:

If $\mathrm{p}>0.05$ then $\mathrm{H} 0$ (hypothesis is rejected) and

If $\mathrm{p}<0.05$ then $\mathrm{H} 1$ (hypothesis is accepted)

Ho: The developed problem solving-based e-module is unable to improve student learning outcomes

H1: E-module based on problem solving developed is able to improve student learning outcomes 


\section{Discussion}

Table 3. Media Expert Validation Results

\begin{tabular}{|c|c|c|c|c|}
\hline Aspect & No. & Question Items & Result & Criteria \\
\hline \multirow{10}{*}{ Display Aspects } & 1. & E-module start page design & 2 & \multirow{19}{*}{$\begin{array}{c}\text { Very } \\
\text { Worth it }\end{array}$} \\
\hline & 2. & Design of e-module content page & 2 & \\
\hline & 3. & Design concepts with subjects & 3 & \\
\hline & 4. & Color selection on writing & 3 & \\
\hline & 5. & Color selection on images / charts & 4 & \\
\hline & 6. & $\begin{array}{l}\text { The colors in the text contrast against the } \\
\text { background }\end{array}$ & 4 & \\
\hline & 7. & Selection of background on e-module & 3 & \\
\hline & 8. & Color selection for the background & 4 & \\
\hline & 9. & Image placement in the module & 4 & \\
\hline & 10. & Layout of the entire module content & 3 & \\
\hline \multirow{8}{*}{ Usage aspect } & 11. & Users find it easy to operate the e-module & 3 & \\
\hline & 12. & $\begin{array}{l}\text { The help function assists the module's } \\
\text { electronic operation }\end{array}$ & 2 & \\
\hline & 13. & $\begin{array}{l}\text { There are text / pictures in color in the } \\
\text { module }\end{array}$ & 3 & \\
\hline & 14. & $\begin{array}{l}\text { The colors in the writing are not } \\
\text { conspicuous for easy reading }\end{array}$ & 3 & \\
\hline & 15. & Navigation buttons are clearly visible & 4 & \\
\hline & 16. & Buttons work for their intended purpose & 4 & \\
\hline & 17. & $\begin{array}{l}\text { The display on the e-module is in } \\
\text { accordance with the learning material }\end{array}$ & 3 & \\
\hline & 18. & Display according to function & 3 & \\
\hline & & Total sc & 57 & \\
\hline
\end{tabular}

Table 4. Results of the Learning Design Expert Validation

\begin{tabular}{|c|c|c|c|c|}
\hline Aspect & No. & Question Items & Result & Criteria \\
\hline \multirow{6}{*}{$\begin{array}{l}\text { Content of the } \\
\text { Material }\end{array}$} & 1. & $\begin{array}{l}\text { Learning objectives in accordance } \\
\text { with competency standards }\end{array}$ & 3 & \multirow{13}{*}{$\begin{array}{c}\text { Well } \\
\text { worth it }\end{array}$} \\
\hline & 2. & $\begin{array}{l}\text { Learning objectives in accordance } \\
\text { with basic competencies }\end{array}$ & 3 & \\
\hline & 3. & $\begin{array}{l}\text { Learning objectives according to the } \\
\text { indicators }\end{array}$ & 3 & \\
\hline & 4. & $\begin{array}{l}\text { Learning objectives in accordance } \\
\text { with the material learning }\end{array}$ & 3 & \\
\hline & 5. & $\begin{array}{l}\text { The material is in accordance with } \\
\text { the indicators of achievement \& KD }\end{array}$ & 3 & \\
\hline & 6. & The material is easy to understand & 3 & \\
\hline \multirow{2}{*}{ Language } & 7. & Beauty display screen & 3 & \\
\hline & 8. & Text legibility & 4 & \\
\hline \multirow{4}{*}{ Presentation } & 9. & Image quality & 4 & \\
\hline & 10. & The material as desired & 3 & \\
\hline & 11. & Video player & 3 & \\
\hline & 12. & Sound and video settings & 2 & \\
\hline \multicolumn{3}{|r|}{ Total score } & 37 & \\
\hline
\end{tabular}


Table 5. Material Expert Validation Results

\begin{tabular}{|c|c|c|c|c|}
\hline Aspect & No. & Question Items & Result & Criteria \\
\hline \multirow{22}{*}{$\begin{array}{c}\text { Self } \\
\text { Insructional }\end{array}$} & 1. & $\begin{array}{l}\text { Learning objectives in accordance with } \\
\text { competency standards }\end{array}$ & 4 & \multirow{23}{*}{$\begin{array}{l}\text { Very } \\
\text { Worth } \\
\text { it }\end{array}$} \\
\hline & 2. & $\begin{array}{l}\text { Learning objectives in accordance with } \\
\text { basic competencies }\end{array}$ & 4 & \\
\hline & 3. & $\begin{array}{l}\text { Learning objectives according to the } \\
\text { indicators }\end{array}$ & 3 & \\
\hline & 4. & $\begin{array}{l}\text { Learning objectives are in accordance } \\
\text { with the learning material }\end{array}$ & 4 & \\
\hline & 5. & Material according to KI \& KD & 4 & \\
\hline & 6. & The material is easy to understand & 4 & \\
\hline & 7. & $\begin{array}{l}\text { The image used is in accordance with the } \\
\text { material }\end{array}$ & 3 & \\
\hline & 8. & $\begin{array}{l}\text { There are pictures that help clarify the } \\
\text { material }\end{array}$ & 4 & \\
\hline & 9. & $\begin{array}{l}\text { There are diagrams / charts that help } \\
\text { explain the material }\end{array}$ & 4 & \\
\hline & 10. & $\begin{array}{l}\text { There are animations or videos that help } \\
\text { explain the material }\end{array}$ & 4 & \\
\hline & 11. & $\begin{array}{l}\text { Practice questions / } / \text { assignments } \\
\text { according to the material being studied }\end{array}$ & 3 & \\
\hline & 12. & $\begin{array}{l}\text { The practice questions / assignments } \\
\text { cover all the material in the learning } \\
\text { module }\end{array}$ & 4 & \\
\hline & 13. & $\begin{array}{lcc}\text { Practice } & \text { questions } / & \text { assignments } \\
\text { encourage } & \text { students to be independent }\end{array}$ & 4 & \\
\hline & 14. & $\begin{array}{l}\text { The language used in the material is } \\
\text { correct }\end{array}$ & 4 & \\
\hline & 15 . & $\begin{array}{l}\text { The sentence in the delivery of the } \\
\text { material is clear }\end{array}$ & 4 & \\
\hline & 16. & $\begin{array}{l}\text { The language style used is easy to } \\
\text { understand }\end{array}$ & 4 & \\
\hline & 17. & $\begin{array}{l}\text { The practice questions for each chapter } \\
\text { serve to deepen the material }\end{array}$ & 3 & \\
\hline & 18. & $\begin{array}{l}\text { The questions cover the learning } \\
\text { objectives }\end{array}$ & 4 & \\
\hline & 19. & $\begin{array}{l}\text { Discussion of answers to questions } \\
\text { provides more explanation }\end{array}$ & 3 & \\
\hline & 20. & $\begin{array}{l}\text { The learning material grid that must be } \\
\text { mastered is contained in the content }\end{array}$ & 4 & \\
\hline & 21. & The library used is clear & 4 & \\
\hline & 22. & The library used is trusted & 3 & \\
\hline \multirow[t]{2}{*}{ Self Contained } & 23. & $\begin{array}{l}\text { The content of the material is in } \\
\text { accordance with the competency } \\
\text { standards in the syllabus }\end{array}$ & 4 & \\
\hline & & & & \\
\hline
\end{tabular}




\begin{tabular}{|c|c|l|c|}
\hline \multirow{3}{*}{ Stand Alone } & 24. & $\begin{array}{l}\text { Fill in the material according to the basic } \\
\text { competencies in the syllabus }\end{array}$ & 4 \\
\cline { 2 - 4 } & 25. & $\begin{array}{l}\text { All the required material is included in } \\
\text { the module }\end{array}$ & 4 \\
\hline Adaptive & 26. & $\begin{array}{l}\text { The distribution of material is adjusted to } \\
\text { KI / KD }\end{array}$ & 4 \\
& 27. & $\begin{array}{l}\text { References from the internet have clear } \\
\text { literary sources }\end{array}$ & 3 \\
\cline { 2 - 4 } & 28. & $\begin{array}{l}\text { E- The learning module refers to the } \\
\text { developing science and technology }\end{array}$ & 3 \\
\hline \multirow{3}{*}{ User Friendly } & 29. & $\begin{array}{l}\text { Pictures / charts - existing charts provide } \\
\text { more explanation about the material }\end{array}$ & 4 \\
\cline { 2 - 4 } & 30. & $\begin{array}{l}\text { The application example given is to } \\
\text { provide an overview to students }\end{array}$ & 3 \\
\hline
\end{tabular}

Table 6. Small Group Trial Results

\begin{tabular}{|c|c|c|c|c|c|c|c|}
\hline \multirow[t]{2}{*}{ Aspect } & \multirow{2}{*}{$\begin{array}{l}\mathbf{N} \\
\mathbf{0}\end{array}$} & \multirow[t]{2}{*}{ Description } & \multicolumn{3}{|c|}{$\begin{array}{l}\text { Alternativ } \\
\text { e Answers }\end{array}$} & \multirow[t]{2}{*}{\begin{tabular}{|l} 
total \\
Score
\end{tabular}} & Criteria \\
\hline & & & \begin{tabular}{l|l}
1 & 2
\end{tabular} & 3 & 4 & & \\
\hline & 1. & $\begin{array}{ll}\text { Display e-module } & \text { design } \\
\text { according to subjects }\end{array}$ & & 1 & 4 & 19 & \\
\hline & 2. & $\begin{array}{l}\text { All e-module components are of } \\
\text { the appropriate size }\end{array}$ & & & 5 & 20 & \\
\hline & 3. & The layout layout is correct & & 2 & 3 & 18 & \\
\hline & 4. & Text is easy to read & & 2 & 3 & 18 & \\
\hline & 5. & The text size is correct & & 4 & 1 & 16 & \\
\hline & 6. & The type of text used & 1 & 3 & 1 & 15 & \\
\hline Media Ouality & 7. & $\begin{array}{l}\text { Images are available in the e- } \\
\text { module to make it easier for me } \\
\text { to understand the learning } \\
\text { material }\end{array}$ & 2 & 2 & 1 & 14 & \\
\hline & 8. & $\begin{array}{l}\text { The images are presented } \\
\begin{array}{l}\text { according to the learning } \\
\text { material }\end{array}\end{array}$ & 1 & 4 & & 14 & $\begin{array}{c}\text { Very } \\
\text { Worth it }\end{array}$ \\
\hline & 9. & Interesting image & 2 & 3 & & 13 & \\
\hline & $\begin{array}{l}1 \\
0 .\end{array}$ & $\begin{array}{l}\text { Users find it easy to operate the } \\
\text { e-module }\end{array}$ & 4 & & 1 & 12 & \\
\hline & $\begin{array}{l}1 \\
1 .\end{array}$ & $\begin{array}{l}\text { Navigation buttons are clearly } \\
\text { visible }\end{array}$ & 3 & 1 & 1 & 13 & \\
\hline & $\begin{array}{l}1 \\
2 .\end{array}$ & $\begin{array}{l}\text { Buttons work for their intended } \\
\text { purpose }\end{array}$ & 1 & 4 & & 14 & \\
\hline & $\begin{array}{l}1 \\
3 .\end{array}$ & $\begin{array}{l}\text { The developed e-module is more } \\
\text { interesting than the print module }\end{array}$ & 2 & 2 & 1 & 14 & \\
\hline Material & $\begin{array}{l}1 \\
4 .\end{array}$ & $\begin{array}{l}\text { This E-Module describes the } \\
\text { material }\end{array}$ & 2 & 3 & & 13 & \\
\hline Quality & 1 & Content of material according to & 1 & 2 & 2 & 16 & \\
\hline
\end{tabular}




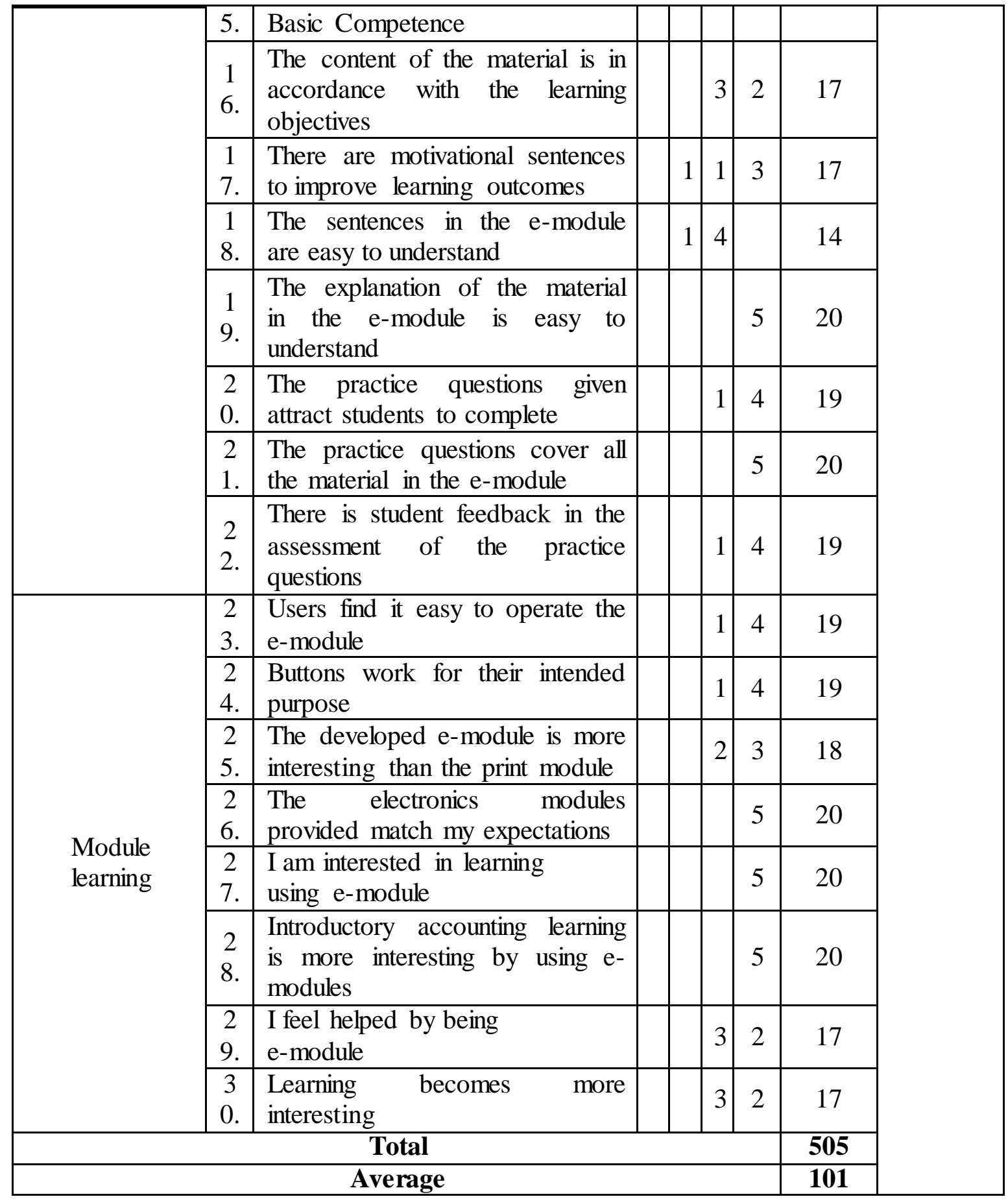

Assessment on the limited field trial was also carried out at the faculty of economics against the AA4 class, namely 20 students, the mean score for all aspects of 1963 was in the range of scores. $1950<\mathrm{XI} \leq 2400$. So that all aspects of limited field trials for e-module based on problem solving introduction to accounting 1 are categorized as "Very feasible". And there are no problems that need to be fixed. Thus e-module learning is ready to be tested for its effectiveness.

The results of the validation by media experts, learning design experts and material experts, each aspect of the overall assessment is determined by the average score in their respective categories. The results of the assessment are then analyzed to determine the appropriateness of the product developed for use in Accounting Introduction I learning. 
The average percentage of the validation results from media experts, learning design experts and material experts will be described as follows:

1. Based on the media expert validator data, the mean score for all aspects of 61 is in the score range $58.5<\mathrm{XI} \leq 72$. For the percentage of the feasibility level of the media expert validator, it is obtained $80.26 \%$ so that the product in terms of media falls into the category "Very Worth".

2. Based on the data from the learning design expert validator, the mean score for all aspects of 36 is in the $30<\mathrm{XI} \leq 39$ score range. The percentage of the feasibility level of the design expert validator is $75 \%$ so that the product in terms of learning design falls into the "Eligible" category. ".

3. Based on the material expert validator data, the mean score for all aspects of 111 is in the score range $97.5<\mathrm{XI} \leq 120$. For the percentage of the feasibility level of the media expert validator, it is obtained $92.5 \%$ so that the product in terms of material falls into the category "Very Worth".

Based on the response from the small group trial, the mean score for all aspects of 505 was obtained in the score range of $487.5<\mathrm{XI} \leq 600$. For the percentage of the feasibility level of the media expert validator, it was obtained $84.16 \%$ so that the product in terms of material was included in the category "Very Worth".

Based on the response from the small group trial, the mean score for all aspects of 1963 was in the 1950 score range $<\mathrm{XI} \leq 2400$. For the percentage of the feasibility level of the media expert validator was $81.79 \%$ so that the product in terms of material was included in the category " Very Worth it".

Hypothesis test

The hypothesis proposed in this study is that there is a significant difference between the learning outcomes of students who are taught using conventional developed e-modules. The formula used to test the hypothesis is the -t test, namely the independent sample test.

The results of data processing obtained a sig (2-tailed) value of $0.01<$ from 0.05 . The terms of effectiveness as previously described are if the significant level is p (Sig (2tailed)) if $\mathrm{p}>0.05$ then $\mathrm{H} 0$ (rejected) and if $\mathrm{p}<0.05$ then $\mathrm{H} 1$ (accepted). Based on these results, it means that $\mathrm{H} 1$ is There is a difference (increase) in learning outcomes between the experimental class and the control class, meaning that the developed problem solvingbased e-module can improve learning outcomes Introduction to Accounting I for students of the Faculty of Economics, University of HKBP Nomensen Medan.

Table 7. Independent Sample Tests

\begin{tabular}{|c|c|c|c|c|c|c|c|c|c|}
\hline & \multicolumn{2}{|c|}{$\begin{array}{l}\text { Levene's Test } \\
\text { for Equality } \\
\text { of Variances }\end{array}$} & \multicolumn{7}{|c|}{ t-test for Equality of Means } \\
\hline & $\mathrm{F}$ & Sig. & $\mathrm{t}$ & df & $\begin{array}{l}\text { Sig. }(2- \\
\text { tailed) }\end{array}$ & $\begin{array}{c}\text { Mean } \\
\text { Difference }\end{array}$ & $\begin{array}{l}\text { Std. Error } \\
\text { Difference }\end{array}$ & $\begin{array}{r}95 \% \mathrm{Co} \\
\text { Interva } \\
\text { Diffe }\end{array}$ & $\begin{array}{l}\text { fidence } \\
\text { of the } \\
\text { ence }\end{array}$ \\
\hline & & & & & & & & Lower & Upper \\
\hline $\begin{array}{l}\text { Equal variances } \\
\text { Learni assumed } \\
\text { ng } \\
\text { outcom } \\
\text { es } \quad \begin{array}{l}\text { Equal variances not } \\
\text { assumed }\end{array}\end{array}$ &, 401 &, 529 & $\begin{array}{l}-2,651 \\
-2,651\end{array}$ & 66 & $\begin{array}{l}, 010 \\
, 010\end{array}$ & $\begin{array}{l}-5.35294 \\
-5.35294\end{array}$ & $\begin{array}{l}2,01885 \\
2,01885\end{array}$ & $\begin{array}{l}-9.38371 \\
-9,38437\end{array}$ & $\begin{array}{l}-1.32218 \\
-1.32151\end{array}$ \\
\hline
\end{tabular}


Also by comparing the average learning outcomes of the experimental group with the average learning outcomes of the control group, where if the mean value of the learning outcomes of students taught using e-module based on problem solving (experiment) is obtained $>$ than the mean value of student learning outcomes without e. Developed module (control) means the product is effectively used.

The learning outcomes obtained by semester 1 students in introductory accounting courses with an average learning outcome of83,0294 using conventional modules and using products developed student learning outcomes with an average of 88.3824. The statistical table can be seen as follows:

Table 8. Mean Group Statistics Table

\begin{tabular}{|ll|r|r|r|r|}
\hline & Class & N & \multicolumn{1}{c|}{ Mean } & Std. Deviation & Std. Mean Error \\
\hline Learning & KK & 34 & 83,0294 & 8,70557 & 1,49299 \\
outcomes & TO & 34 & 88,3824 & 7,92394 & 1.35894 \\
\hline
\end{tabular}

Thus the increase in learning outcomes proves that problem solving-based e-modules are effectively used as a medium of learning both from lecturers and students, so in other words thata module is said to be effective if the goal is achieved in the form of learning outcomes, effective and in use.

The product of e-module learning development in the Scope of Accounting, Basic Equations and Journaling is Introduction to Accounting I material that has been developed with attention to aspects of learning and media as the principles of learning message design. This product development research is directed to produce a product in the form of e-module learning in the Introduction to Accounting I course which is used to improve the learning process and student competencies. Therefore, in the process this research was carried out by starting a preliminary study, then designing the learning media, validating the product and making revisions and improvements based on validation data analysis from media experts, learning design experts and material experts which was then continued with small group trials,

The benefits of using e-module learning are that the concepts presented are easy to learn, understand and systematic. E-modules provide opportunities for students to learn at their own pace, learn faster, independently and interestingly because they are equipped with audio and video tutorials which supports the material presented as well as various practice questions. There is a repetition that must be done when the wrong answer makes students better understand and master the material. This learning e-module can also be used as a learning medium online or individually.

Revised and refined aspects based on data analysis and trials and input from media experts, learning design experts, material experts and students as users of this learning emodule, aim to explore some common aspects in the process of developing a product. Learning media variables have a very good average value. The learning media variables that are assessed include the feasibility of content, presentation, language, programming, and graphics.

The use of e-modules as media and learning tools has a higher level of effectiveness than the use of power point media. This can be seen from the results of the average value of Introduction to Accounting for Students learning with e-module which is 88.3824, while the average value of Introduction to Accounting I for students with e-module learning Power Point is 83.0294. Based on these data, it proves that the use of e-module learning is better in improving student learning outcomes in the Introduction to Accounting I course compared to the use of PowerPoint learning media. 
However, in this study, it was obtained data that students 'learning outcomes of Introduction to Accounting I were higher by using e-module learning than students' learning outcomes of Introduction to Accounting I of students who were taught with PowerPoint learning media, but in practice these two learning media were able to improve understanding and results. learn Introduction to Accounting I student.

\section{Conclusion}

The results of the validation from the media expert on the introductory accounting emodule I that have been developed include the display and usage aspects, which show that the feasibility of learning media is considered very feasible with an average percentage of $80.26 \%$. Thus the e-module developed using the sigil application and Azardi / reasily as a "reader" application is overall included in the "Very Appropriate" category.

The results of validation from learning design experts on the developed e-module learning include aspects of material content, linguistic aspects, and aspects of presentation show that the quality of the learning design is considered feasible with an average percentage of $75 \%$. Based on the results of the validation, it was concluded that the emodule Introduction to Accounting I developed was included in the eligibility criteria so that it could be accepted and fit for use in the learning process.

The results of validation from learning material experts on the developed e-module learning include aspects of self-instructional, self contained, stand alone, adaptive, and user friendly. It shows that the quality of the learning design is considered feasible with an average percentage of $92.5 \%$. Based on the results of the validation, it was concluded that the e-module Introduction to Accounting I which was developed was included in the criteria of "Very Appropriate" so that it could be accepted and used in the learning process.

Based on the responses and responses of students from the Faculty of Economics, University of HKBP Nomensen Medan in small group trials based on aspects of media quality, material quality and module learning, it was stated that the e-module developed was very feasible with an average percentage of $84.16 \%$. Thus the e-module developed as a whole is included in the criteria of "Very Eligible"

Based on the responses and responses of students from the Faculty of Economics, University of HKBP Nomensen Medan on a limited field trial based on aspects of media quality, material quality and module learning, it was stated that the e-module developed was very feasible with an average percentage of $81.79 \%$. Thus the e-module developed as a whole is included in the criteria of "Very Eligible"

The e-module learning developed by the researcher is suitable for use as a learning media for Introduction to Accounting I for students, because it has a higher mean value of 88.3824> 83.0294 mean value without using the e-module developed.

The emodule developed proved to be effective in improving learning outcomes based on the level of significance with the independent sample test with a Sig (2-tailed) of $0.01<0.05$ so that it can be concluded that the e-module developed was effective in improving student learning outcomes of introductory accounting I. 


\section{References}

Muhson A, (2020). Penerapan Metode Problem Solving Dalam Pembelajaran Statistika Lanjut. Diambil dari artikel Staffnew.uny.acid pada tanggal 27 Oktober 2020

Arikunto, Suharsimi. (2012). Prosedur Penelitian. Jakarta: Rineka Cipta

Borg, W \& Gall,M.D. (2003). Educational Research : An Introduction Seventh Edition Boston: Pearson Education, Inc.

Dick \& Carey. (2005), The Systematic Design of Instruction, Pearson: Boston Dimyati dan Mudjiono. (2006). Belajar dan Pembelajaran. Jakarta: Rieke Cipta

Donelly.R \& Fitzmaurice. M.(2005). Design Modules for Learning. Dublin-AISHE

Fadloli. A. R (2017) "Peningkatan Hasil Belajar Pada Mata Pelajaran Simulasi Digital Menggunakan Media Pembelajaran Sigil Melalui Pendekatan Kontekstual Siswa Kelas XTE SMK Muhammadiyah Prambanan": Jurnal Pendidikan Teknik Mekatronika, Vol 7.No. 1 (Diakses 20 Januari 2020)

Gagne \& Wagner. (2005). Principles of instruction Design. $5^{\text {th }}$ ed. USA: Thomson Wadsworth.

Gagne,dkk. (1993). The Cognitive Psychology of School Learning. HarperCollins College Publishers.

Imron.H, Mentari.S (2017). "Development of Accounting E-Module to Support the Scientific the Approach of Students Grade X Vocational High School'. Journal of Accounting and Business Education. Vol. 1

Maharani, dkk. (2015), "Pemanfaatan Software Sigil Sebagai Media Pembelajaran ELearning Yang Mudah, Murah Dan User", Seminar Nasional Teknologi Informasi dan Multimedia, pp. 25-30 https://docplayer.info/53358179-Pemanfaatan-softwaresigil-sebagai-media-pembelajaran-e-learning-yang-mudah-murah-dan-user-friendlydengan-format-epub-sebagai-sumber-materi.html diakses tanggal 13-03-2020

Resien, Sitompul, H., and Situmorang, J. (2020). The Effect of Blended Learning Strategy and Creative Thinking of Students on the Results of Learning Information and Communication Technology by Controlling Prior Knowledge. Budapest International Research and Critics in Linguistics and Education (BirLE) Journal Vol 3 (2): 879-893.

Rose, D., Meyer, A. \& Strangman, N. (2002). Teaching Every Student In the Digital Age: Universal Design for Learning. United States: ASCD Publishing Company

Sadiman, dkk. (2011). Media Pendidikan: Pengertian, Pengembangan, dan Pemanfaatannya Jakarta: Rajawali Pers

Skinner, B.F. (2013) Ilmu Pengetahuan dan Perilaku Manusia. Yogyakarta: Pustaka Pelajar

Slamento. (2010) Belajar dan Faktor yang Mempengaruhinya. Jakarta: Rineka Cipta,

Suarsana \& Mahayukti, (2013), Pengembangan E-Modul Berorientasi Pemecahan Masalah Untuk Meningkatkan Keterampilan Berpikir Kritis Mahasiswa", Jurnal Pendidikan Indonesia, Vol.2.No.2, (Diakses tanggal 15 Januari 2020)

Sudjana, N. (2009). Penilaian hasil proses belajar mengajar. Bandung: PT Remaja Rosdakarya.

Sugiyono, (2013), Metode Penelitian Pendidikan (Pendekatan Kuantitatif Kualitatif dan $R \& D$. Bandung: Alfabeta

Sujarweni. V.W. (2019). Pengantar Akuntansi 2. Yogyakarta: Pustaka Baru

Suprihatiningrum, J., (2013), Strategi Pembelajaran; Teori dan Implikasi, Yogyakarta : Ar Ruzz Media. 
Suwarjdono (2012). Teori Akuntansi. Yogyakarta: BPFE

Taswan. (2008). Akuntansi Perbankan. Yogyakarta: UPP STIM YKPN

Trianto. (2014). Model Pembelajaran Terpadu: Konsep, Strategi, dan Implementasinya dalam Kurikulum Tingkat Satuan Pendidikan (KTSP). Jakarta: Bumi Aksara.

Utomo, M.R., Hasruddin, and Murad, A. (2020). Influence of Problem Based Learning Models (PBL) and Learning Motivation to Learn Outcomes and Student's Critical Thinking Skills Themes of Caring for Life in Class IV Primary School No 026609 Pujidadi Binjai. Budapest International Research and Critics in Linguistics and Education (BirLE) Journal Vol 3 (4): 1634-1643. 